\title{
Permian fossil insects of North-East Europe: new and little-known Ideliidae (Insecta, Plecopteroidea, Grylloblattida)
}

\author{
Sergey Storozhenko
}

Storozhenko, S. 1992: Permian fossil insects of North-East Europe: new and little-known Ideliidae (Insecta, Plecopteroidea, Grylloblattida). — Entomol. Fennica 3:21-39.

New Permian taxa of the family Ideliidae from North-East Europe are described and the genus Permotermopsis Martynov is revised. New taxa: Stenaropodites sojanensis sp. n., S. mistshenkoi sp. n., S. magna sp. n.; Idelinella macroptera gen. et sp. n.; Idelina kamensis gen. et sp. n.; Khosaridelia martynovi gen. et sp. n.; Sojanidelia gen. n.; S. maculosa sp. n.; S. fasciata sp. n.; S. multimediana sp. n.; S. vorkutensis sp. n.; S. longula sp. n.; S. parvula sp. n.; S. nana sp .n.; S. makarkini sp. n.; S. fluctuosa sp. n.; S. lineata sp. n. and S. striata sp. n. A key to 12 species of Sojanidelia is given, and one species, S. kostinae (Sharov, 1961) comb. n., is transferred from Metidelia Martynov to Sojanidelia gen. n.

Sergey Storozhenko, Institute of Biology and Pedology, Far East Branch of Academy of Sciences of USSR, 690022, Vladivostok, USSR

\section{Introduction}

In most modern classifications the order Grylloblattida (= Paraplecoptera + Protoperlaria + Grylloblattida) belongs to the superorder Plecopteroidea (Rasnitsyn 1980). The following families of the Grylloblattida are known (Sharov 1962, Kukalova 1964, Rasnitsyn 1980, Hennig 1981, Storozhenko 1988):

Carboniferous - Narkemdae and Protoperlidae; Carboniferous-Permian - Ideliidae;

Permian - Lemmatophoridae, Liomopteridae, Demopteridae, Camptoneuritidae, Chelopteridae, Protembiidae, Phenopteridae, Sylvaphlebiidae, Euremiscidae, Havlatidae, Jabloniidae, Skaliciidae, Probnisidae, Stereopteridae, Euryptilonidae, Tillardembidae, Archiprobnisidae and Permoneuridae;

Permian-Triassic - Megakhosaridae;

Permian - Lower Cretaceous - Blattogryllidae; Triassic - Tomiidae and Mesorthopteridae;

Triassic-Jurassic — Geinitziidae;
Lower Cretaceous - Oecanthoperlidae; and Recent - Grylloblattidae.

The family Atactophlebidae was recently transferred from the order Grylloblattida to the order Gerarida (Storozhenko 1990).

The terminology of the wing-venation is adopted from Sharov (1962), Kukalova (1964) and Hennig (1981). Since only $M P$ and $C u P$ are concave (or groove-shaped) in the fore wing of the family Ideliidae, the symbols for convex $(+)$ and concave (-) wing veins are omitted from the figures.

The present study is based on material deposited in the Paleontological Institute, Academy of Sciences of USSR, Moscow. This material was collected by the expeditions of the Laboratory of Paleoentomology of the Paleontological Institute. All materials are from the following wellknown Permian localities: the Sojana River in the Arkhangelsk region, the Kitjak River in the Kirov region, Tichije Gory on the Kama River and Vorkuta in the Komi ASSR. 


\section{Description of new taxa}

\section{Order Grylloblattida Walker, 1914}

\section{Family Ideliidae M. Zalessky, 1929}

Type genus: Idelia M. Zalessky, 1929 = Stenaropodites Martynov, 1928.

Diagnosis: Fore wing with $S c$ terminating on $C$, costal area broad with numerous veinlets, $M$ not united with $R$ in proximal third of wing, $M A$ branched in distal part of wing, $C u A$ with numerous pectinate branches, $C u A_{2}$ not distinct, archedictyon or irregular cross-veins present in all areas. The family Ideliidae is closely related to the families Archiprobnisidae, Megakhosaridae, Blattogryllidae, Mesorthopteridae and Liomopteridae (Rasnitsyn 1980). The Archiprobnisidae differs from Ideliidae by the very broad areas between $R, R S, M A, M P$ and $C u A$ with parallel simple cross-weins (Sharov 1962). The Megakhosaridae and Blattogryllidae are distinguished from Ideliidae by the simple S-shaped cross-veins in the $\mathrm{CuA}-\mathrm{CuP}$ area (Sharov 1961, Rasnitsyn 1976, Storozhenko 1988). The Mesorthiopteridae differs from the Ideliidae in having $M$ close to or united with $R$ in the proximal third of the fore wing (Rasnitsyn 1980). The Liomopteridae is distinguished from Ideliidae by the distinct, usually simple $C u A_{2}$ (Sharov 1962, Kukalova 1964).

Genera included: Upper Carboniferous Korshakolia Sharov, 1961; Permian Stenaropodites Martynov, 1928 (= Idelia M. Zalessky, 1929), Metidelia Martynov, 1937, Permotermopsis Martynov, 1937, Rachimentomon G. Zalessky, 1939, Sylvidelia Martynov, 1940, Kolvidelia G.Zalessky, 1955, Archidelia Sharov, 1961, Aenigmidelia Sharov, 1961, and Paridelia Sharov, 1961 (Sharov 1962). The genus Austroidelia Riek, 1954, described from the Triassic of Australia (Riek 1954), was transferred to the family Mesorthopteridae by Rasnitsyn (1980). The Lower Permian genus Permula Handlirsh, 1919 is the only genus of the family Liomopteridae in which $C u A$ sends off a pectinate series of branches and $C u A_{2}$ is indistinct (Kukalova 1964), and it may therefore belong to the family Ideliidae. Four new genera are described below.

\section{Stenaropodites Martynov, 1928}

Type species: Stenaropodites reticulata Martynov, 1928, Upper Permian of Kama River (Tikhije Gory); by original designation.

Species included: S. reticulata Martynov, 1928 and S. permiakovae (M. Zalessky, 1929) are known from the Upper Permian of Tikhije Gory. Three new species are described below.

\section{Stenaropodites sojanensis Storozhenko, sp. n.} Figs. 1, 2.

Holotype: Fore wing, imprint and counter-imprint, specimen No 3353/146; USSR: Arkhangelsk region, right bank of Sojana River about $57 \mathrm{~km}$ from its mouth, IvaGora; Upper Permian, Kazanian Stage; in collection of Paleontological Institute, Moscow.

Material: Holotype and 29 paratypes (all from Sojana River: Iva-Gora, Sheimo-Gora and Letopala): fore wing, specimens No 3353/160, 3353/240, 3353/311, 3353/322, $3353 / 1117,94 / 1126,362 / 117 \& 372 / 117,374 / 117,722 /$ $117,794 / 117,979 / 117 \& 798 / 117,814 / 117,817 / 117,835 /$ $117 \& 840 / 117,846 / 117,860 / 117,866 / 117$ and $2645 / 117$; hind wing, specimens No 3353/174, 3353/343, 103/117, $104 / 117,111 / 117,356 / 117,384 / 117 \& 486 / 117,508 / 117$ \& 509/117, $786 / 117$ and 888/117.

Locality and occurrence: USSR: Sojana River (IvaGora, Sheimo-Gora and Letopala); Upper Permian: Kazanian Stage.

Description: Fore wing about 3 times longer than broad, with rounded apex. Costal area with 17-18 simple or branched veinlets; ratio of its width to maximum width of radial area 1.8-2.0. $S c$ terminating at or before three-quarters of wing length; subcostal area narrow. $R S$ originating before first third of wing, with $4-5$ branches. $M$ dividing before origin of $R S$; $M A$ with 4-5 branches; MP simple. CuA with 9-12 branches; proximal 4-5 branches terminating on $C u P$ or disappearing in $\mathrm{CuA}-\mathrm{CuP}$ area; distal 4 branches curving upwards. $C u P$ straight. $A_{1}$ simple, Sshaped. $A_{2}$ with 4-5 curved or $\mathrm{S}$-shaped branches. Archedictyon present in all areas. Fore wing light, with dark brown longitudinal stripes between veins; costal area dark brown with light veinlets and archedictyon. Hind wing with rounded apex. Costal, subcostal and radial areas very narrow. $R S$ with 9-10 branches. $M$ fused shortly with $C u A$ near base. $C U A$ with 3-4 branches; $C u P$ simple. Anal lobe enlarged. $A_{1}$ weakly developed. $A_{2}$ 

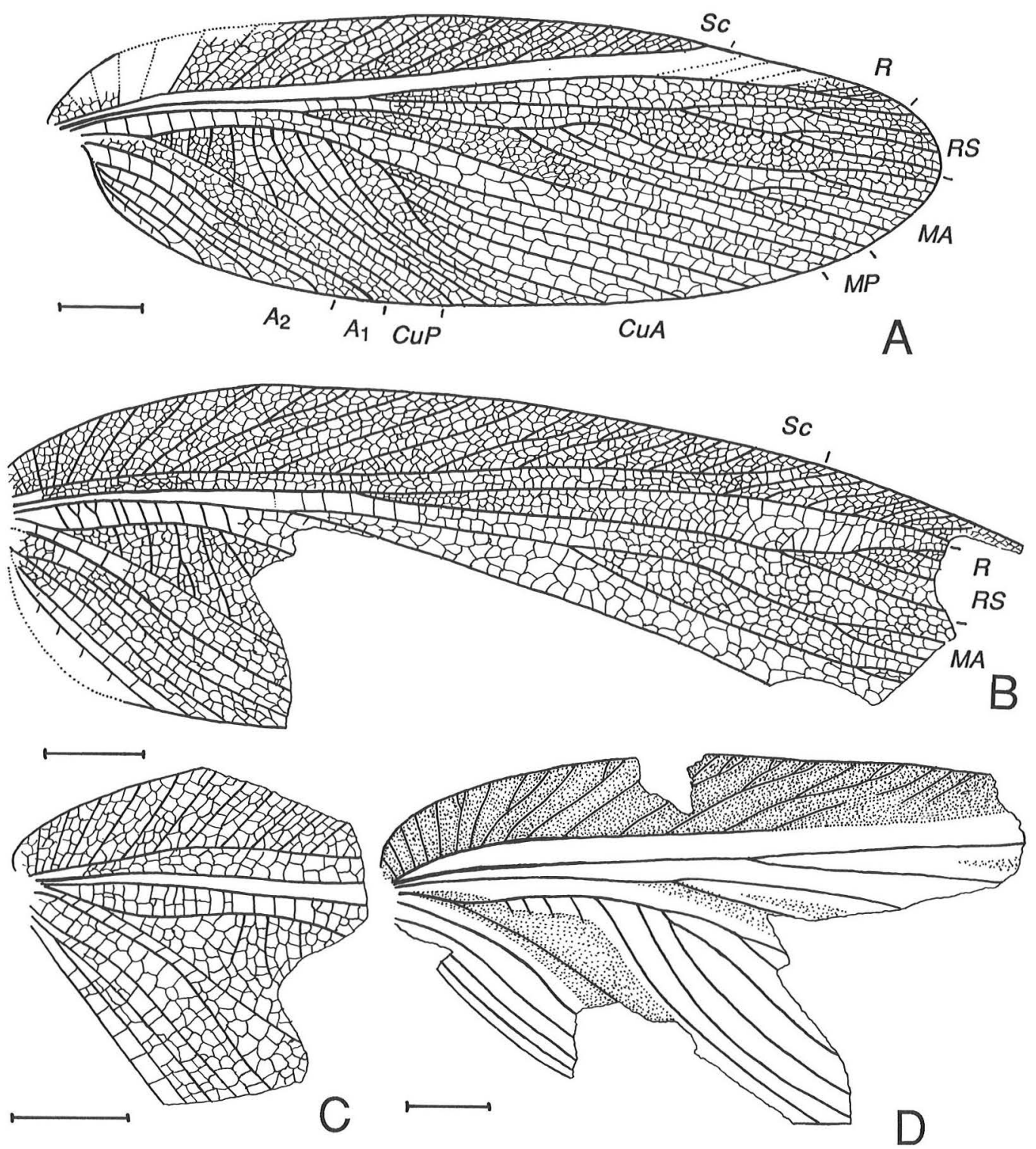

Fig. 1. Stenaropodites sojanensis sp. n., fore wing. - A: holotype, spec. No 3353/146; B: paratype, spec. No 3353/240; C: paratype, spec. No 3353/160; D: paratype, spec. No 3353/311. - Scale bars 5 mm.

with numerous branches. Hind wing light; costal area brown. Length of fore wing 50-57 mm, width of fore wing 18.8-19.5 mm. Length of hind wing $43-47 \mathrm{~mm}$. Maximum width of costal area of fore wing $3.5-4.5 \mathrm{~mm}$, of hind wing 1.5$1.7 \mathrm{~mm}$.
The fore wing of Stenaropodites sojanensis differs from that of $S$. reticulata Martynov, 1928 and S. permiakovae (M. Zalessky, 1929) by 4 long distal upwards curving branches of $C u A$ while only 2 such branches are known in the related species. 

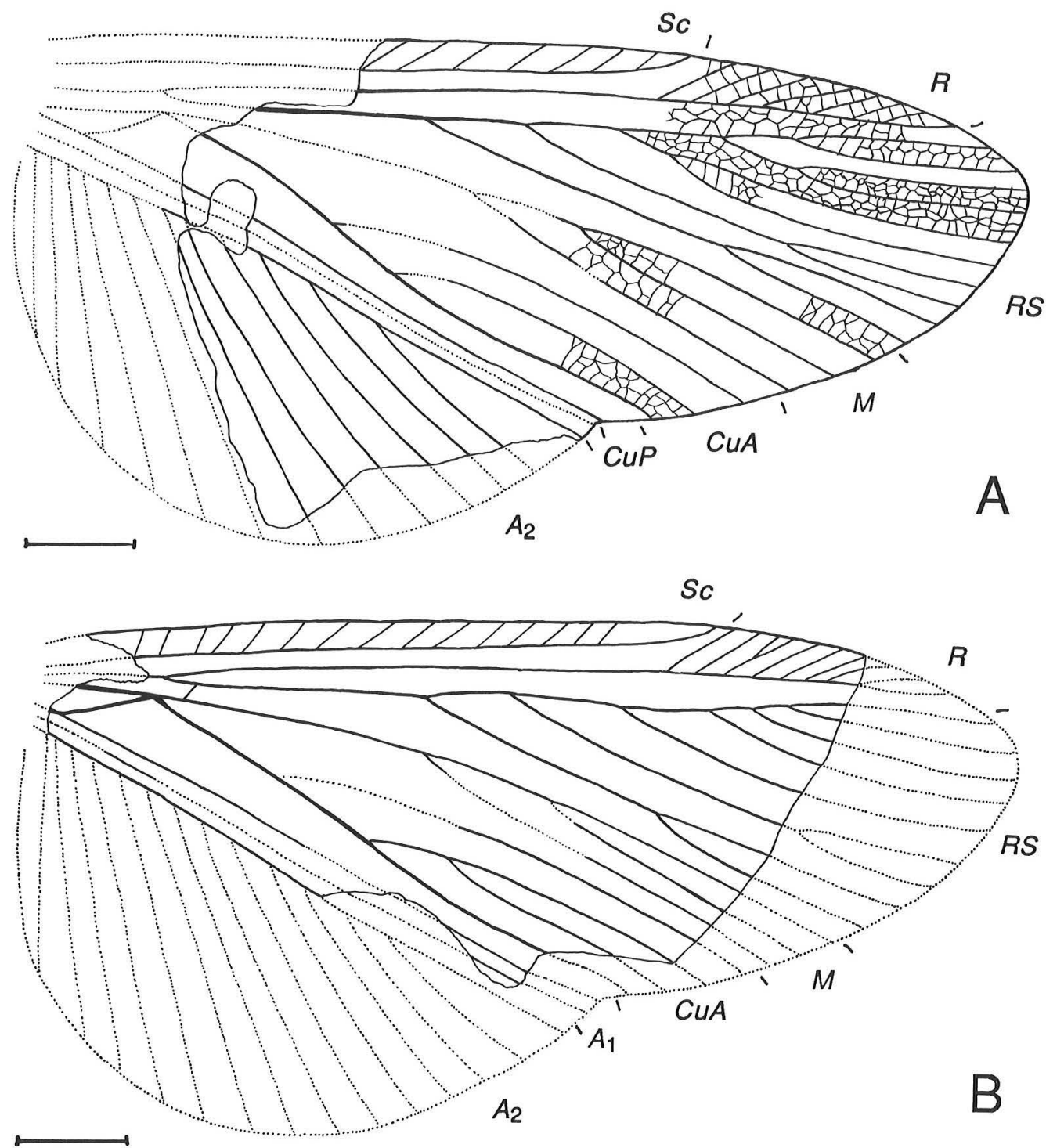

Fig. 2. Stenaropodites sojanensis sp. n., hind wing, paratypes. - A: spec. No 3353/174; B: spec. No 3353/343. - Scale bars $5 \mathrm{~mm}$.

Stenaropodites mistshenkoi Storozhenko, sp. n. Fig. 3.

Holotype: Fore wing, imprint and counter-imprint, specimen No 801/117 \& 804/117; USSR: Arkhangelsk region, right bank of Sojana River, about $57 \mathrm{~km}$ from its mouth, Iva-Gora; Upper Permian: Kazanian Stage; in collection of Paleontological Institute, Moscow.

Material: Holotype and 5 paratypes (all from Sojana River: Iva-Gora and Letopala): fore wing, specimens No $3353 / 323,793 / 117$ and $353 / 117 \& 836 / 117$; hind wing, specimens No 3353/219 and 803/117.
Locality and occurrence: USSR: Sojana River (IvaGora and Letopala); Upper Permian: Kazanian Stage.

Description: Fore wing about 3 times longer than broad, with rounded apex. Costal area with a series of 11-17 simple or branched veinlets; ratio of its width to maximum width of radial area 1.4-1.6. Subcostal area narrow. $R S$ with 7-8 branches. $M A$ with 3-5 branches, $M P$ with 2 branches. Distal branch of $M A$ sometimes shortly fused with $R S$. Archediction present in all areas. Fore wing light, with brown longitudinal 


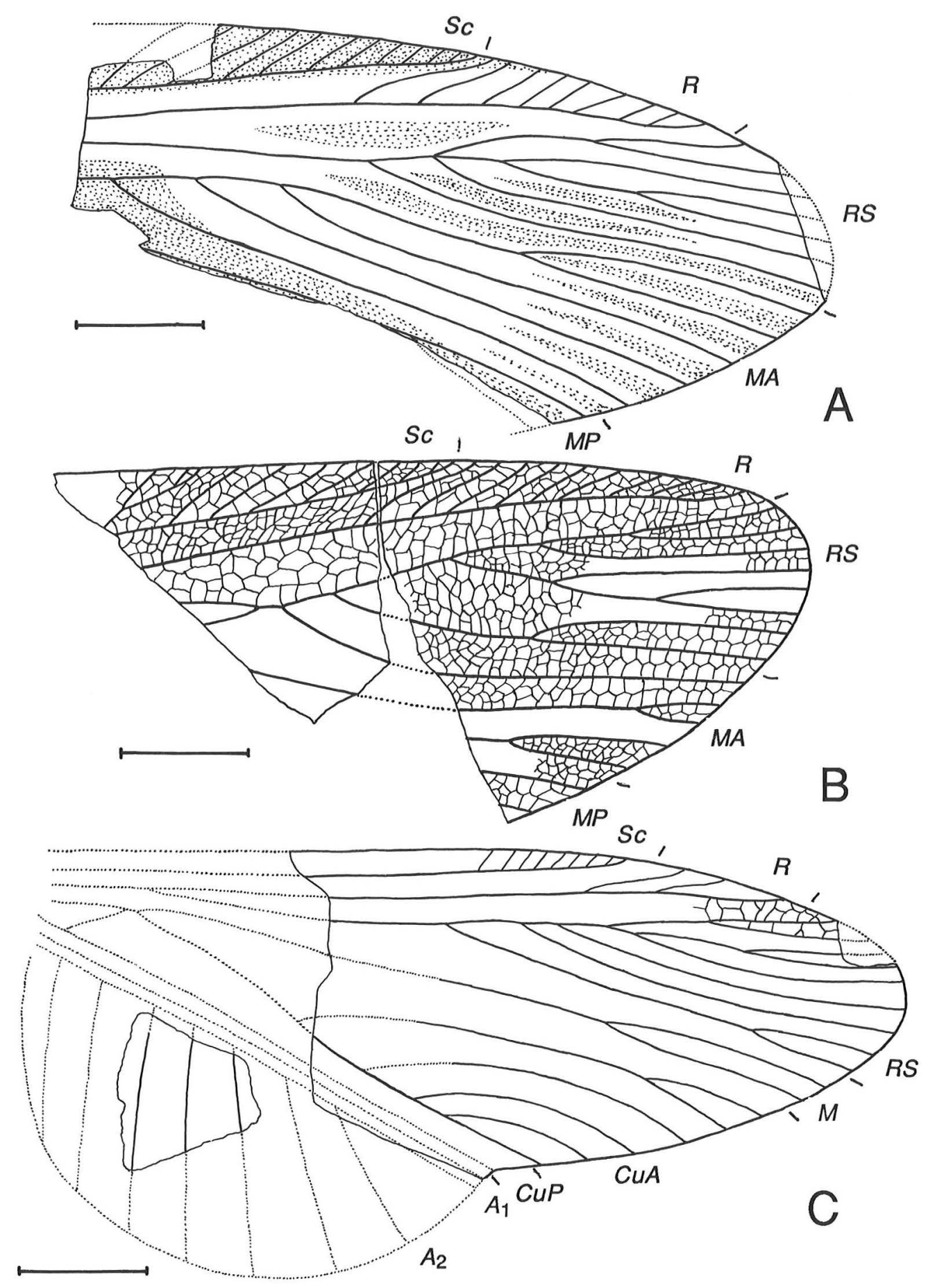

Fig. 3. Stenaropodites mistshenkoi sp. n. - A: fore wing, holotype, spec. No 804/117 \& 801/117; B: fore wing, paratype, spec. No 3353/323; C: hind wing, paratype, spec. No 3353/219. - Scale bars $5 \mathrm{~mm}$. 
stripes between veins; costal area brown. Hind wing with very narrow costal area. $R S$ with 9 branches. $M$ with 2 branches, fused shortly with $C u A$ near base. $C u A$ with 6 branches. Anal lobe strongly enlarged. $A_{1}$ simple; $A_{2}$ with numerous branches. Hind wing light, costal area dark. Length of fore wing 41-53 mm, of hind wing $40.5 \mathrm{~mm}$. Maximum width of costal area of fore wing 2.8-3.1 mm, of hind wing 1.0-1.1 mm.

S. mistshenkoi is closely related to $S$. sojanensis, but differs by the more branched $R S$ of the fore wing and by the more narrow costal area of the fore and hind wings.

Named in honour of Dr. L. L. Mistshenko, the well-known Russian orthopterologist.

\section{Stenaropodites magna Storozhenko, sp. n.} Fig. 4A

Holotype: Anterior half of fore wing, imprint and counter imprint, specimen No 1366/239; USSR: Kirov region, left bank of Kitjak River near village of Bolshoj Kitjak (= Big Kitjak); Upper Permian: Tatarian Stage; in collection of Paleontological Institute, Moscow.

Material: Holotype only.

Locality and occurrence: USSR: Kitjak River; Upper Permian: Tatarian Stage.

Description: Fore wing long, probably with rounded apex. Costal area with a series of 18 simple or branched veinlets; ratio of its width to maximum width of radial area $1.9 . S c$ terminating at about $2 / 3$ of wing length. $R S$ originating at about first third of wing, with 4 branches. $M$ dividing before origin of RS. CuA with 6 branches, 3 directed posteriorly and 3 anteriorly. $C u P$ and $A_{1}$ probably simple; $A_{2}$ probably branched. Cross-veins numerous, irregular. Wing light, with dark costal area. Length of fore wing about $65-67 \mathrm{~mm}$; width of costal area $6.2 \mathrm{~mm}$.

S. magna differs from all known species of the genus Stenaropodites by the large size and by the 3 distal anteriorly directed branches of $C u A$.

\section{Idelinella Storozhenko, gen. $\mathrm{n}$.}

Type species: Idelinella macroptera sp. n.; Upper Permian of Sojana River, USSR.

Description: Fore wing membranous, without hairs. Costal area broad, with numerous sim- ple veinlets. Main fork of $M$ proximal to origin of $R S . C u A$ with a long fork: $C u A_{1}$ with $4, C u A_{2}$ with 2 branches. $C u P$ simple, straight. $A_{1}$ with 2 , $A_{2}$ with 4 branches. Very dense archedictyon present in all areas except costal area.

Idelinella is closely related to Stenaropodites, Sylvidelia and Archidelia, but differs by the presence of simple veinlets in the costal area and by a long fork of $C u A$ parallel with $C u P$.

Species included: Type species only.

\section{Idelinella macroptera Storozhenko, sp. $\mathrm{n}$.}

Fig. 4B

Holotype: Basal half of fore wing, imprint and counter imprint, specimen No 94/129 \& 94/130; USSR: Arkhangelsk region, right bank of Sojana River about $56 \mathrm{~km}$ from its mouth, Sheimo-Gora; Upper Permian: Kazanian Stage; in collection of Paleontological Institute, Moscow.

Material: Holotype only.

Locality and occurrence: USSR: Sojana River (SheimoGora); Upper Permian: Kazanian Stage.

Description: Costal area of fore wing probably with a series of 25-30 simple veinlets. Subcostal area narrow, its width 3.5 times less than width of costal area. RS, MA and MP broken. Wing light, without spots or stripes, veins light. Length of fore wing $60-65 \mathrm{~mm}$, width $19.7 \mathrm{~mm}$.

\section{Idelina Storozhenko, gen. $\mathrm{n}$.}

Type species: Idelina kamensis sp. n.; Upper Permian of Kama River, USSR.

Description: Fore wing membranous, without hairs. Sc terminating on $C$ near apical quarter of wing; costal area relatively narrow, only 1.05 times broader than maximum width of radial area; costal area with about 20 simple veinlets. $R$ simple, $R S$ with 4 branches, dichotomous. $M$ forked proximally to origin of $R S$; $M P$ branched. $C u A$ with 7 branches. $C u A-C u P$ area with irregular, partly S-shaped veinlets. $C u P$ simple, slightly curved. $A_{1}$ with 5 branches. Cross-veins mostly irregular, forming rows of two or three cells; cross-veins in radial area slanted in the opposite direction than in other areas; in $R S-M A$ area and anal area cross-veins almost straight. Anal area short. 

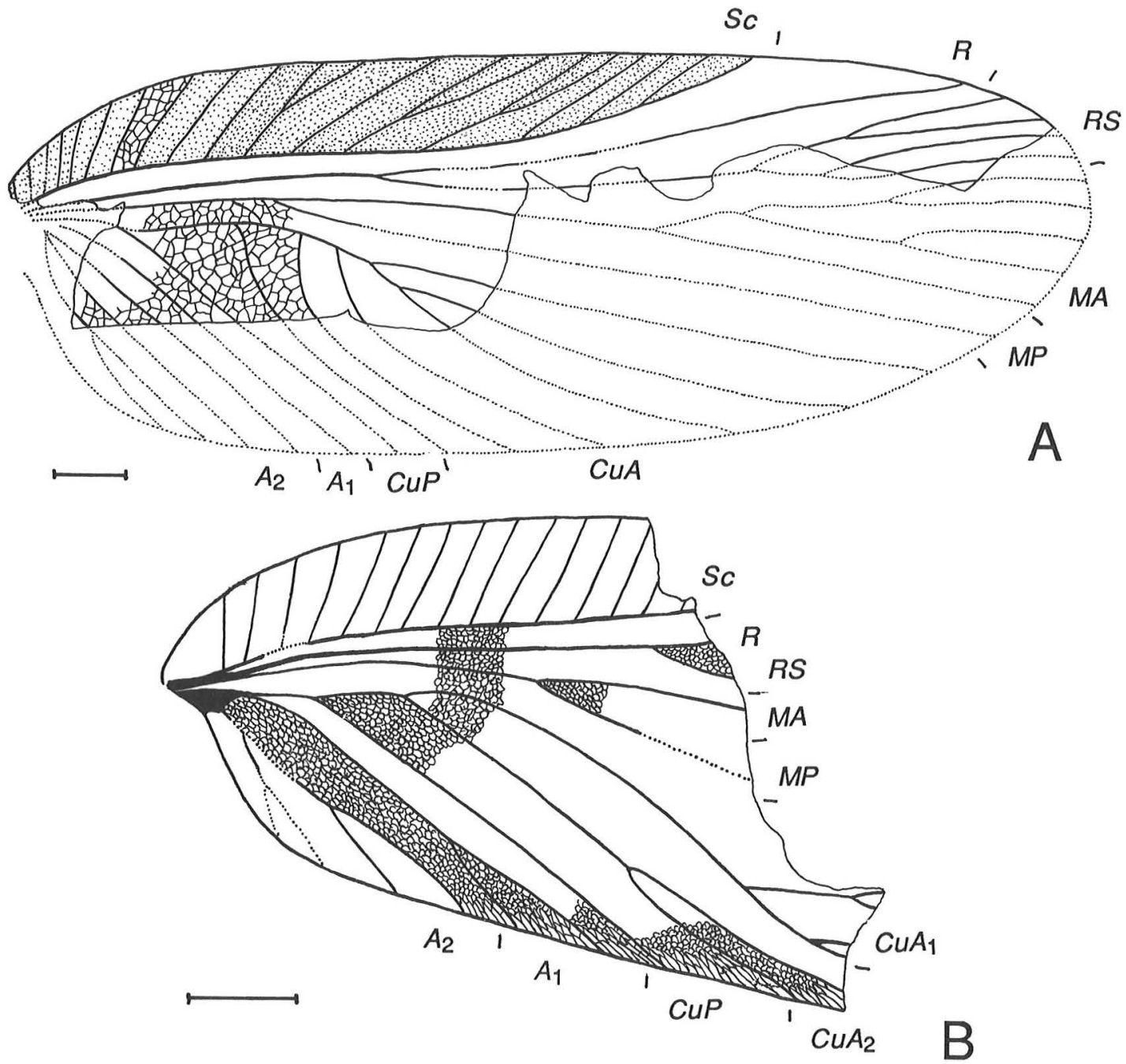

Fig. 4. Fore wings of Ideliidae. - A: Stenaropodites magna sp. n., holotype, spec. No 1366/239. - B: Idelinella macroptera sp. n., holotype, spec. No 94/129 \& 94/130. - Scale bars 5 mm.

Idelina is related to Paridelia and to Khosaridelia, but easily distinguished by a shorter anal area with 5-branched $A_{1}$ and by dense and more irregular cross-veins, slanted in the opposite direction than in the radial area.

Species included: Type species only.

\section{Idelina kamensis Storozhenko, sp. n.}

Fig. 5A

Holotype: Imprint of fore wing, specimen No 1259/1; USSR: Kama River, Tikhije Gory; Upper Permian: Kaza- nian Stage; in collection of Paleontological Institute, Moscow.

Material: Holotype only.

Locality and occurrence: USSR: Kama River (Tikhije Gory); Upper Permian: Kazanian Stage.

Description: Fore wing about 3.2 times longer than broad. Subcostal area broad, its width 1.2 times less than width of costal area. $R S$ originating at about first quarter of the wing, dichotomous. $M A$ with 2 branches, $M P$ pectinated, with 3 branches; $A_{1}$ with 5 branches, $A_{2}$ with 4 branches. Wing light, without spots or stripes; veins dark. Length of fore wing $48 \mathrm{~mm}$, width $15 \mathrm{~mm}$. 

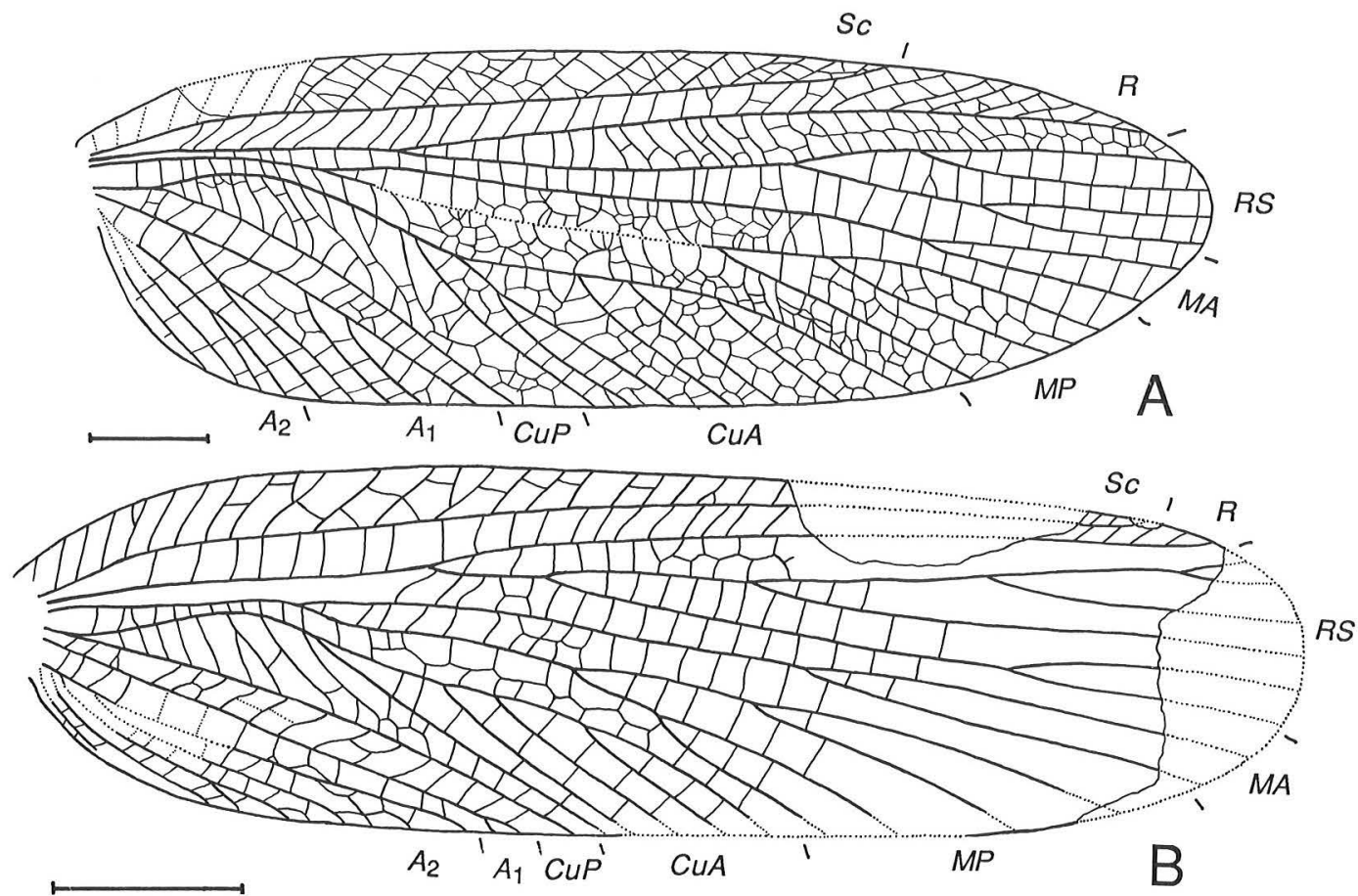

Fig. 5. Fore wings of Idelidae. —A: Idelina kamensis sp. n., holotype, spec. No 1259/1; B: Khosaridelia martynovi sp. n., holotype, spec. No 1631/363. — Scale bars $5 \mathrm{~mm}$.

\section{Khosaridelia Storozhenko, gen. n.}

Type species: Khosaridelia martynovi sp. n.; Lower Permian of Vorkuta, USSR.

Description: Fore wing membranous, without hairs. $S c$ terminating on $C$ near apex of wing; costal area relatively narrow, only 1.35 times broader than maximum width of radial area; costal area with more than 30 simple or branched veinlets. $R$ simple; $R S$ with 6 branches, pectinate. $M$ forked proximally to the origin of $R S ; M P$ branched. $C u A$ with 13 branches; 8 proximal branches straight or slightly S-shaped, disappearing in $\mathrm{CuA}-\mathrm{Cu} P$ area. $C u P$ simple, straight. $A_{1}$ simple. Cross-veins mostly regular, straight, forming rows of two irregular cells in the $R-R S$, $R S-M A, M A-M P$ and $M P-C u A$ areas. Anal area long.

Khosaridelia is related to Paridelia, but differs by 6 branches of $R S$ and by distinct branches of $C u A$ in $C u A-C u P$ area. In partly S-shaped branches of $C u A$ in $C u A-C u P$ area and mostly straight cross-veins the new genus is similar to representatives of the family Megakhosaridae, but is easily distinguished from these by the broader costal area with simple cross-veins and sometimes branched veinlets. Undoubtedly the Megakhosaridae originated from the Ideliidae by forms closely related to Khosaridelia.

Species included: Type species only.

\section{Khosaridelia martynovi Storozhenko, sp. n.} Fig. 5B

Holotype: Imprint of fore wing, specimen No 1631/ 363; USSR: Komi ASSR, Vorkuta; Lower Permian; in collection of Paleontological Institute, Moscow.

Material: Holotype only.

Locality and occurrence: USSR: Vorkuta; Lower Permian.

Description: Fore wing about 3.4 times longer than broad. Subcostal area broad, its width 1.5 times less than width of costal area. $R S$ originating at about the first third of wing, pectinate. $M A$ with 2 branches, MP dichotomous, with 4 
branches. $A_{1}$ simple, straight. $A_{2}$ with 5 branches. Length of fore wing $34.3 \mathrm{~mm}$, width $10.0 \mathrm{~mm}$.

Named in honour of Prof. A. V. Martynov, the founder of modern paleoentomology.

\section{Sojanidelia Storozhenko, gen. n.}

Type species: Sojanidelia maculosa sp. n.; Upper Permian of Sojana River, USSR.

Description: Fore wing membranous, without hairs. $S c$ terminating on $C$ near apical third or quarter of wing; costal area relatively narrow or broad, with 11-23 simple or branched veinlets. $R$ simple, $R S$ simple or with 2-5 branches, curved upwards. First fork of $M$ proximal to origin of $R S$; $M A$ with 2-5 branches, $M P$ simple or bifurcated. $C u A$ with $6-12$ branches; $1-5$ proximal straight or slightly curved branches disappearing in $C u A-C u P$ area; distal 3-5 branches of $C u A$ upwards curving. $C u P$ simple, straight. $A_{1}$ simple, straight or S-shaped; $A_{2}$ with 2-4 branches. Archedictyon present. Anal area short.

Sojanidelia is closely related to Paridelia Sharov, 1961, Metidelia Martynov, 1937 and Rachimentomon G. Zalessky, 1939. From Paridelia and Metidelia it differs by the upwards curved distal branches of $C u A$ and by the very numerous and irregular cross-veins. Rachimentomon is easily distinguished from Sojanidelia by the S-shaped pectinated $R S$ curving downwards.

Species included: There are 12 species from Lower Permian and Upper Permian, 11 of them described below. Sharov (1961) described Metidelia kostinae, but on the basis of the wingvenation this species must be transferred to Sojanidelia.

As all the species are included in the key below, no specific diagnoses are given.

\section{Key to the species of Sojanidelia}

1. Length of fore wing 22-29.5 mm; maximum width of costal area $1.0-1.9 \mathrm{~mm}$..

- Length of fore wing 32-39 $\mathrm{mm}$; maximum width of costal area $2.0-2.8 \mathrm{~mm}$......................................... 9

2. $R S$ with 3-4 branches ............................................... 3

- $R S$ simple or only with 2 branches ........................... 8

3. $M$ with 7 branches ...........................S. multimediana

- $M$ with 4-5 branches
4. Length of fore wing 25-29.5 mm. Maximum width of costal area $1.4-1.9 \mathrm{~mm}$......................................... 5

- Length of fore wing 22-24 mm. Maximum width of costal area $1.0-1.3 \mathrm{~mm}$........................................... 7

5. Fore wing without spots. $M$ with 4 branches S. makarkini

- Fore wing with dark spots. $M$ with 5 branches ......... 6

6. Fore wing with large spots. Length of wing 24-26 mm. Maximum width of costal area 1.5-1.8 $\mathrm{mm}$....... S. maculosa

- Fore wing with small spots. Length of wing $29.5 \mathrm{~mm}$. Maximum width of costal area $1.4 \mathrm{~mm}$......S. longula

7. $R S$ with 4 branches; MA with 2. Costal area broader than radial area. Lower Permian of Kuznetsk basin, USSR S. kostinae

- $R S$ with 3 branches; MA with 3. Radial area broader than costal area .......................................... f fasciata

8. Fore wing without spots. RS with 2 branches. Distal branch of $C u A$ simple .................................. parvula

- Fore wing with large dark spots. RS simple. Distal branch of $C u A$ bifurcate .................................. nana

9. Fore wing without spots or stripes. Maximum width of costal area 2.5-2.8 mm ........................................ 10

- Fore wing with longitudinal dark stripes across veins and costal area. Maximum width of costal area 2.0$2.3 \mathrm{~mm}$........................................................ 11

10. Distal branch of $C u A$ with 3 branches. $R S$ not anastomosed with $M A$. Length of fore wing 32-34 mm S. fluctuosa

- Distal branch of $C u A$ simple. $R S$ anastomosed with $M A$. Length of fore wing $39 \mathrm{~mm}$................... v. vorkutensis

11. RS not united with $M A$, anastomosis between them absent. Distal branch of $C u A$ mostly simple $S$. lineata

- RS united with MA or distinct anastomosis between them present. Distal branch of $C u A$ always bifurcate . S. striata

\section{Sojanidelia maculosa Storozhenko, sp. n.}

Fig. 6A, B

Holotype: Imprint of fore wing, specimen No 3353/ 136; USSR: Arkhangelsk region, right bank of Sojana River about $57 \mathrm{~km}$ from its mouth, Iva-Gora; Upper Permian: Kazanian Stage; in collection of Paleontological Institute, Moscow.

Material: Holotype and 4 paratypes (all from Sojana River: Iva-Gora): fore wing, specimen No 3353/271, 3353/ 278, 1431/117 and 2334/277 \& 2334/278.

Locality and occurrence: USSR: Sojana River (IvaGora); Upper Permian: Kazanian Stage.

Description: Fore wing 2.85-3.0 times longer than broad, with broadly rounded apex. Costal area with a series of 17-18 simple or branched veinlets; costal area 5.1-5.6 times narrower than maximum width of wing. $R S$ originating at about 
first third of wing, with 3-4 branches. Maximum width of radial area 1.1-1.4 times less than width of costal area. $M$ with 5 branches: $M A$ with 3-4, $M P$ simple or with 2 branches. CUA with 8-10 branches; 3-4 proximal ones disappear in $C u A-$ $C u P$ area; distal branch of $C u A$ simple. $A_{1}$ simple, slightly S-shaped; $A_{2}$ with 3-4 branches. Dense archedictyon present in all areas. Fore wing light, with big black spots. Length of fore wing 23.7$26.1 \mathrm{~mm}$, width 7.9-9.1 mm. Maximum width of costal area $1.5-1.7 \mathrm{~mm}$.

\section{Sojanidelia fasciata Storozhenko, sp. n.} Fig. 6C, D

Holotype: Fore wing, imprint and counter-imprint, specimen No 3353/281; USSR: Arkhangelsk region, right bank of Sojana River about $57 \mathrm{~km}$ from its mouth; IvaGora; Upper Permian: Kazanian Stage; in collection of Paleontological Institute, Moscow.

Material: In addition to holotype one paratype from Sojana River (Iva-Gora): fore wing, specimen No 3353/ 235.

Locality and occurrence: USSR: Sojana River (IvaGora); Upper Permian: Kazanian Stage.

Description: Fore wing 3.1-3.2 times longer than broad, with broadly rounded apex. Costal area with 21-23 simple veinlets; ratio of its width to maximum width of wing 5.75-5.8. $R S$ originating at about first third of wing, with 3 branches. Maximum width of radial area 1.05-1.1 times more than width of costal area. $M$ with 4 branches: $M A$ with 3, $M P$ simple. $C u A$ with 6-9 branches; two proximal branches disappear in $C u A-C u P$ area; distal branch of $C u A$ simple. $A_{1}$ simple, S-shaped. $A_{2}$ with 3 branches. Dense archedictyon present in all areas. Fore wing light, with indistinct dark spots. Length of fore wing 21.9-24.1 mm, width 7.0-7.4 mm. Maximum width of costal area $1.1-1.3 \mathrm{~mm}$.

\section{Sojanidelia multimediana Storozhenko, sp. n.} Fig. 7A

Holotype: Fore wing without basal and apical parts, imprint and counter-imprint, specimen No 1631/368; USSR: Vorkuta; Lower Permian; in collection of Paleontological Institute, Moscow.

Material: Holotype only.
Locality and occurrence: USSR: Vorkuta; Lower Permian.

Description: Fore wing probably about 3 times longer than broad. Costal area broken. $R S$ originating at about first third of wing, with 4 branches. $M$ with 7 branches; $M A$ with $5, M P$ with 2 branches. $C u A$ with more than 6 branches; distal branch of $C u A$ simple. Archedictyon present, cross-veins partly forming rows of two irregular cells in cubital area. Spots or stripes not visible. Length of fore wing about $25-27 \mathrm{~mm}$, width about $8.8 \mathrm{~mm}$.

\section{Sojanidelia vorkutensis Storozhenko, sp. n.} Fig. 7B

Holotype: Imprint of fore wing, specimen No 1631/ 225; USSR: Komi ASSR, Vorkuta; Lower Permian; in collection of Paleontological Institute, Moscow.

Material: Holotype only.

Locality and occurrence: USSR: Vorkuta; Lower Permian.

Description: Fore wing 3.2 times longer than broad, with acutely rounded apex. Costal area with a series of 14-15 simple or bifurcate veinlets; ratio of its width to maximum width of wing 4.65. $R S$ originating at about first third of wing, with 3 branches. Maximum width of radial area 1.85 times less than width of costal area. $M$ with 5 branches: $M A$ with 4 , distal branch of $M A$ anastomosed with $R S ; M P$ simple. $C u A$ with 10 11 branches; two or three proximal branches disappear in $C u A-C u P$ area; distal branch of $C u A$ simple. A1 simple, straight. $A 2$ probably with 3 branches. Cross-veins mostly numerous, irregular; in apical part of $R-R S, R S-M$ and $M-C u A$ area forming rows of two cells. Spots or stripes not visible. Length of fore wing $39 \mathrm{~mm}$, width $12.1 \mathrm{~mm}$. Maximum width of costal area 2.5 $\mathrm{mm}$.

\section{Sojanidelia longula Storozhenko, sp. n.} Fig. 7C

Holotype: Fore wing without anal area, imprint and counter-imprint, specimen No 814/117 \& 869/117; USSR: Arkhangelsk region, right bank of Sojana River about 56$60 \mathrm{~km}$ from its mouth; Upper Permian: Kazanian Stage; in collection of Paleontological Institute, Moscow. 

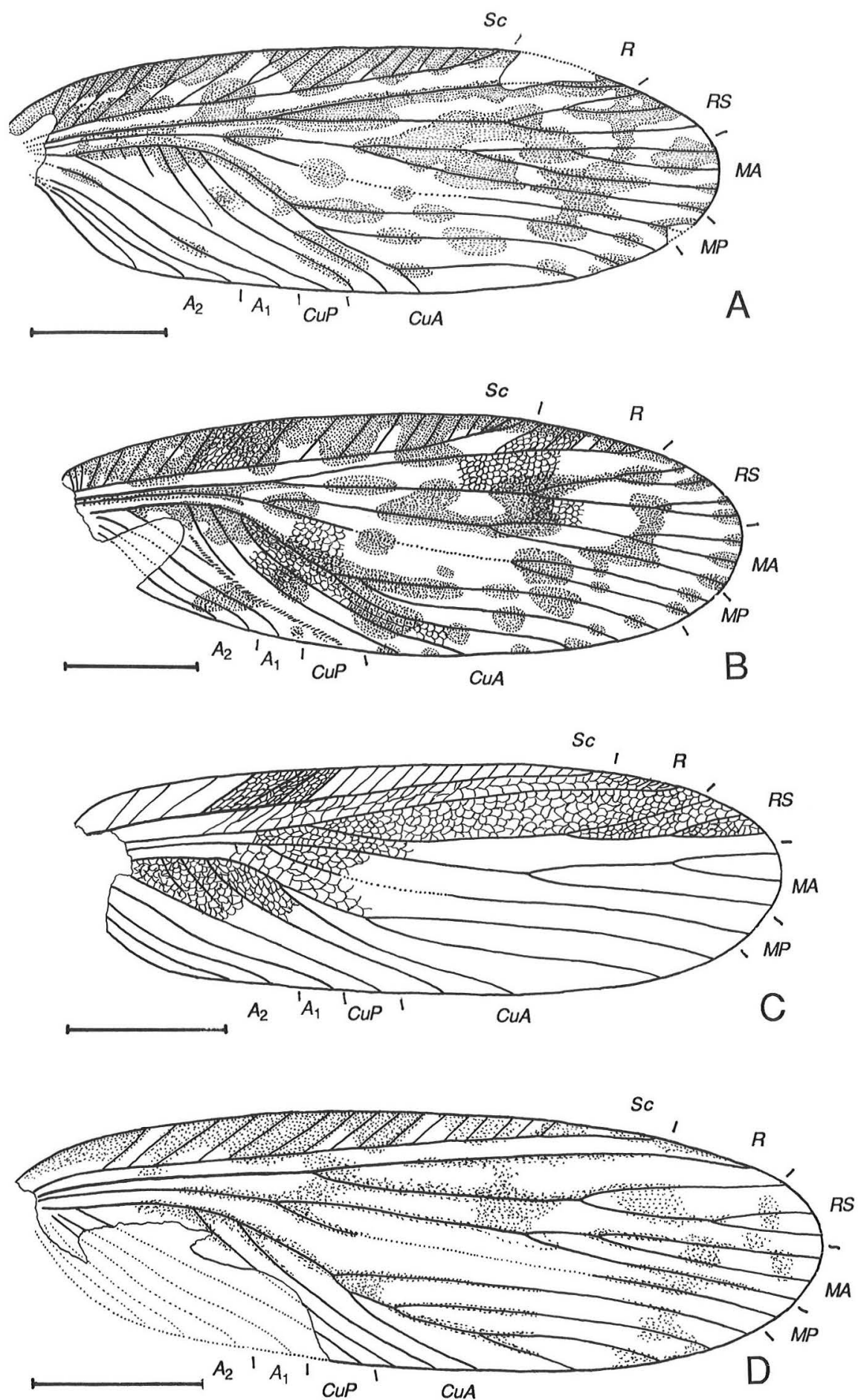

Fig. 6. Fore wings of Sojanidelia. - A, B: S. maculosa sp. n.; A: holotype, spec. No 3353/136; B: paratype, spec. No 3353/278. - C, D: S. fasciata sp. n.; C: holotype, spec. No 3353/281; D: paratype, spec. No 3353/235. Scale bars $5 \mathrm{~mm}$. 

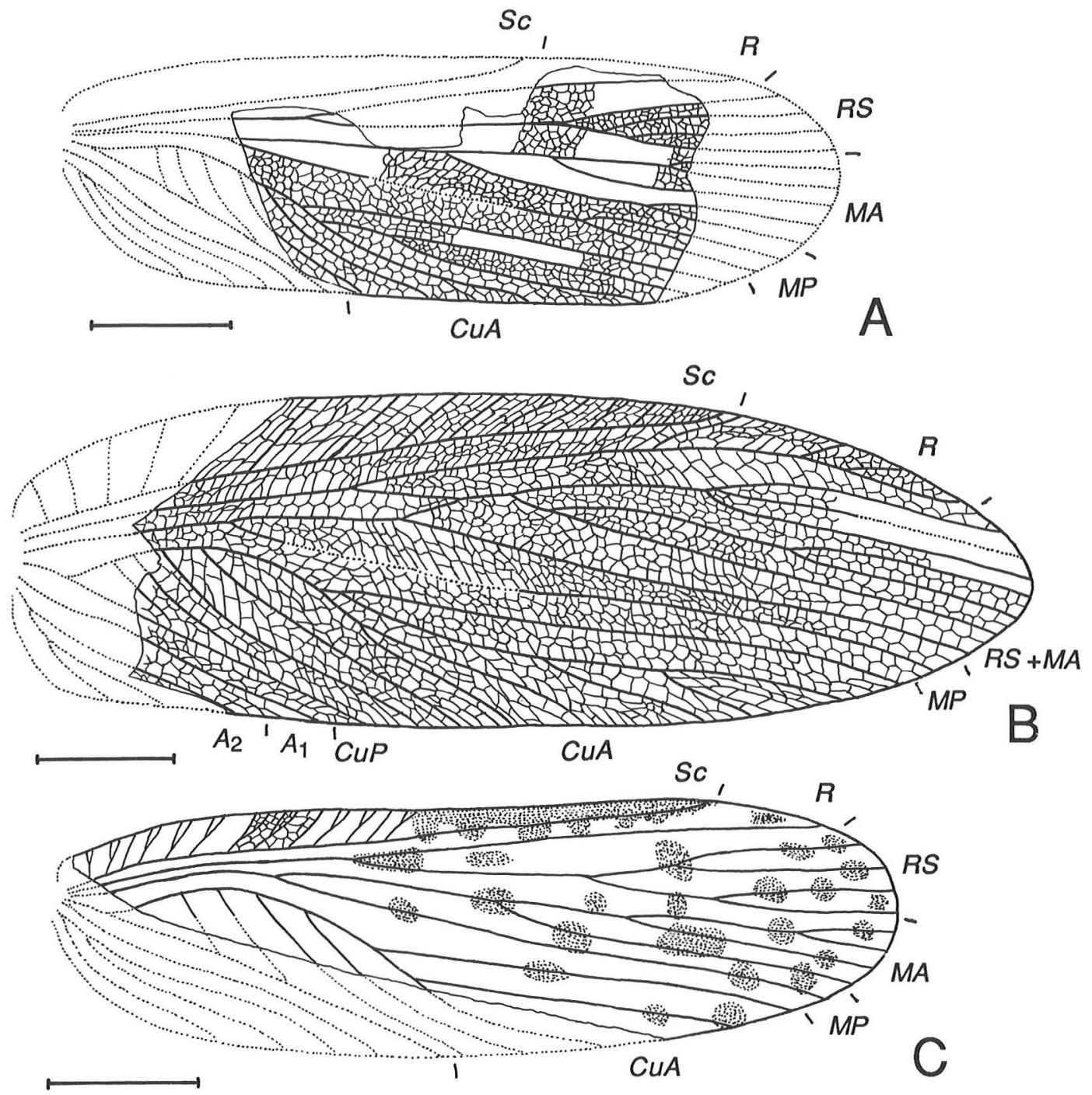

Fig. 7. Fore wings of Sojanidelia. - A: S. multimediana sp. n., holotype, spec. No 1631/368. - B: S. vorkutensis sp. n., holotype, spec. No 1631/225. — C: S. longula sp. n., holotype, spec. No 814/117 \& 869/117. — Scale bars $5 \mathrm{~mm}$.

Material: Holotype only.

Locality and occurrence: USSR: Sojana River; Upper Permian: Kazanian Stage.

Description: Fore wing 3.35 times longer than broad, with broadly rounded apex. Costal area with a series of 19 branched veinlets; narrow: ratio of its maximum width to width of wing 6.3. $R S$ terminating at about first third of wing, with 4 branches. Maximum width of radial area 1.05 times width of costal area. $M$ with 5 branches: $M A$ with 4, MP simple. $C u A$ with 7 branches; two proximal ones disappear in $\mathrm{CuA}-\mathrm{CuP}$ area; distal branch of $C u A$ simple. Dense archedictyon present in all areas. Fore wing light, with little oval dark spots. Length of fore wing $29.5 \mathrm{~mm}$, width $8.8 \mathrm{~mm}$. Maximum width of costal area $1.4 \mathrm{~mm}$. 

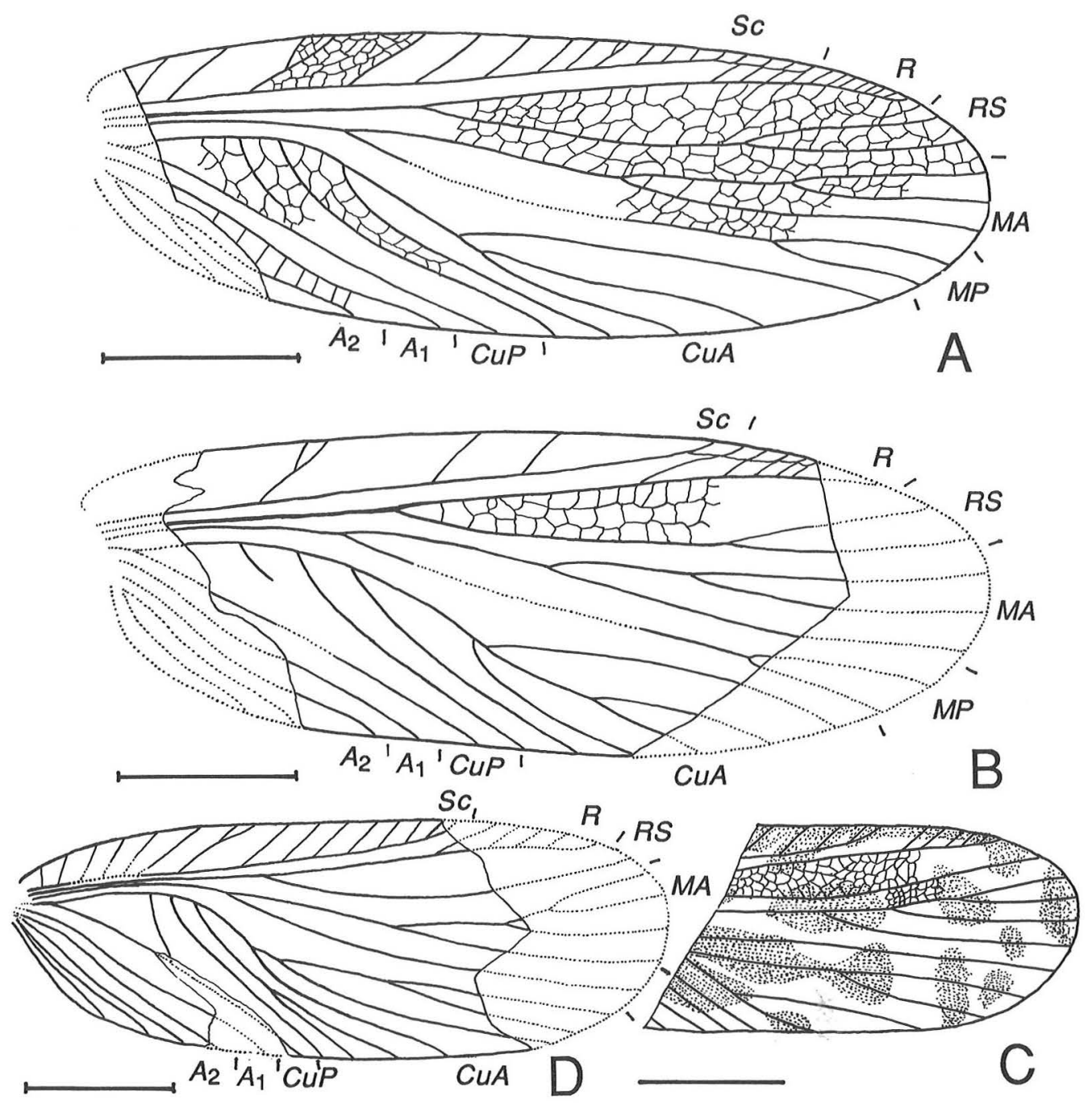

Fig. 8. Fore wings of Sojanidelia. - A, B: S. parvula sp. n.; A: holotype, spec. No 3353/274; B: paratype, spec. No 3353/159. - C, D: S. nana sp. n.; C; holotype, spec. No 94/1122 \& 94/1128; D: paratype, spec. No $3353 / 188$. - Scale bars $5 \mathrm{~mm}$.

\section{Sojanidelia parvula Storozhenko, sp. n.}

Fig. 8A, B

Holotype: Fore wing, imprint and counter-imprint, specimen No 3353/274; USSR: Arkhangelsk region, right bank of Sojana River about $57 \mathrm{~km}$ from its mouth; IvaGora; Upper Permian: Kazanian Stage; in collection of Paleontological Institute, Moscow.

Material: Holotype and 2 paratypes (all from Sojana River: Iva-Gora): fore wing, specimens No $3353 / 159$ and 2642/117.
Locality and occurrence: USSR: Sojana River (IvaGora); Upper Permian: Kazanian Stage.

Description: Fore wing 2.8-2.95 times longer than broad, with broadly rounded apex. Costal area with a series of 11-12 mostly simple veinlets; ratio of its width to maximum width of wing 5.0-5.1. $R S$ originating clearly beyond first third of wing, with 2 branches. Maximum width of radial area and costal ones equal. $M$ with 5 branches; $M A$ with 3, MP with 2 branches. $C u A$ 
with 6-7 branches; one proximal branch disappears in $C u A-C u P$ area; distal branch of $C u A$ simple. $A_{1}$ simple, S-shaped. $A_{2}$ with 3 branches. Archedictyon present only in the costal area; cross-veins forming rows of two cells in most areas and three cells in radial area. Fore wing light, without spots or stripes. Length of fore wing 22.5-25.5 mm, width 7.5-9.0 mm. Maximum width of costal area $1.4-1.7 \mathrm{~mm}$.

\section{Sojanidelia nana Storozhenko, sp. n.} Fig. 8C, D

Holotype: Apical half of fore wing, imprint and counter-imprint, specimen No 94/1122 \& 94/1128; USSR: Arkhangelsk region, right bank of Sojana River about 56$60 \mathrm{~km}$ from its mouth; Upper Permian: Kazanian Stage; in collection of Paleontological Institute, Moscow.

Material: Holotype and 3 paratypes (from Sojana River: about 56-60 km from its mouth and Iva-Gora): fore wing, specimens No 3353/188, 2334/287 and 94/1133.

Locality and occurrence: USSR: Sojana River (IvaGora); Upper Permian: Kazanian Stage.

Description: Fore wing 2.85-3.0 times longer than broad, with broadly rounded apex. Costal area with a series of 13-15 mostly simple veinlets; ratio of its width to width of wing 4.9-5.6. $R S$ originating slightly beyond first third of wing, simple. Maximum width of radial area and costal areas is equal. $M$ with 5 branches: $M A$ with 4 ones, $M P$ simple. $C U A$ with 7-9 branches; one proximal branch disappears in $C u A-C u P$ area; distal branch of $C u A$ divided. $A_{1}$ simple, S-shaped. $A_{2}$ with 4-5 branches. Archedictyon present in all areas. Fore wing light, with large dark spots. Length of fore wing 22-24 mm, width 7.5-8.4 $\mathrm{mm}$. Maximum width of costal area 1.5-1.7 mm.

\section{Sojanidelia makarkini Storozhenko, sp. n.} Fig. 9A

Holotype: Fore wing, imprint and counter-imprint, specimen No 3353/167; USSR: Arkhangelsk region, right bank of Sojana River about $57 \mathrm{~km}$ from its mouth, IvaGora; Upper Permian: Kazanian Stage; in collection of Paleontological Institute, Moscow.

Material: In addition to holotype 4 paratypes (all from Sojana River: Iva-Gora): fore wing, specimens No 94/370, 94/377, 368/117 and 1133/117.

Locality and occurrence: USSR: Sojana River (IvaGora); Upper Permian: Kazanian Stage.
Description: Fore wing 3.0-3.2 times longer than broad, with broadly rounded apex. Costal area with a series of 20-21 mostly simple veinlets; ratio of its width to maximum width of wing 4.8-5.2. $R S$ originating at about the first third of wing, with 3-4 branches. Maximum width of radial area 1.01-1.1 times less than width of costal area. $M$ with 4 branches: $M A$ with 3 branches, $M P$ simple. $C u A$ with 10-11 branches; 4 proximal ones disappear in $C u A-C u P$ area; distal branch of $C u A$ simple. $A_{1}$ simple, S-shaped. $A_{2}$ with 3 branches. Dense archedictyon present in all areas. Fore wing light, without any spots or stripes. Length of fore wing $25.2-28.5 \mathrm{~mm}$, width $8.4-8.7 \mathrm{~mm}$. Maximum width of costal area 1.7$1.9 \mathrm{~mm}$.

Named in honour of the famous neuropterologist Dr. V. N. Makarkin (Vladivostok).

\section{Sojanidelia fluctuosa Storozhenko, sp. n.} Fig. 9B-D

Holotype: Fore wing, imprint and counter-imprint, specimen No 3353/148; USSR: Arkhangelsk region, right bank of Sojana River about $57 \mathrm{~km}$ from its mouth, IvaGora; Upper Permian: Kazanian Stage; in collection of Paleontological Institute, Moscow.

Material: Holotype and 4 paratypes (from Sojana River: about 56-60 km from its mouth and Iva-Gora): fore wing, specimens No 3353/288, 3353/294, 874/117 and 94/675 \& 94/934.

Locality and occurrence: USSR: Sojana River (IvaGora); Upper Permian: Kazanian Stage.

Description: Fore wing 2.9-3.0 times longer than broad, with broadly rounded apex. Costal area with a series of 14-15 simple veinlets; ratio of its width to width of wing 4.2-4.4. $R S$ originating clearly beyond first third of wing, with 4 branches, dichotomous. Maximum width of radial area 1.6-1.7 times less than width of costal area. $M$ with 5 branches: $M A$ with $3, M P$ with 2 branches. $C u A$ with 9-11 branches; one proximal branch disappears in $C u A-C u P$ area; distal branch of $C u A$ divided into 3 branches, pectinate. $A_{1}$ simple, S-shaped. $A_{2}$ with 3 branches. Dense archedictyon present in all areas. Fore wing light, without spots or stripes. Length of fore wing 32 $35 \mathrm{~mm}$, width $11.0-11.3 \mathrm{~mm}$. Maximum width of costal area $2.5-2.8 \mathrm{~mm}$. 

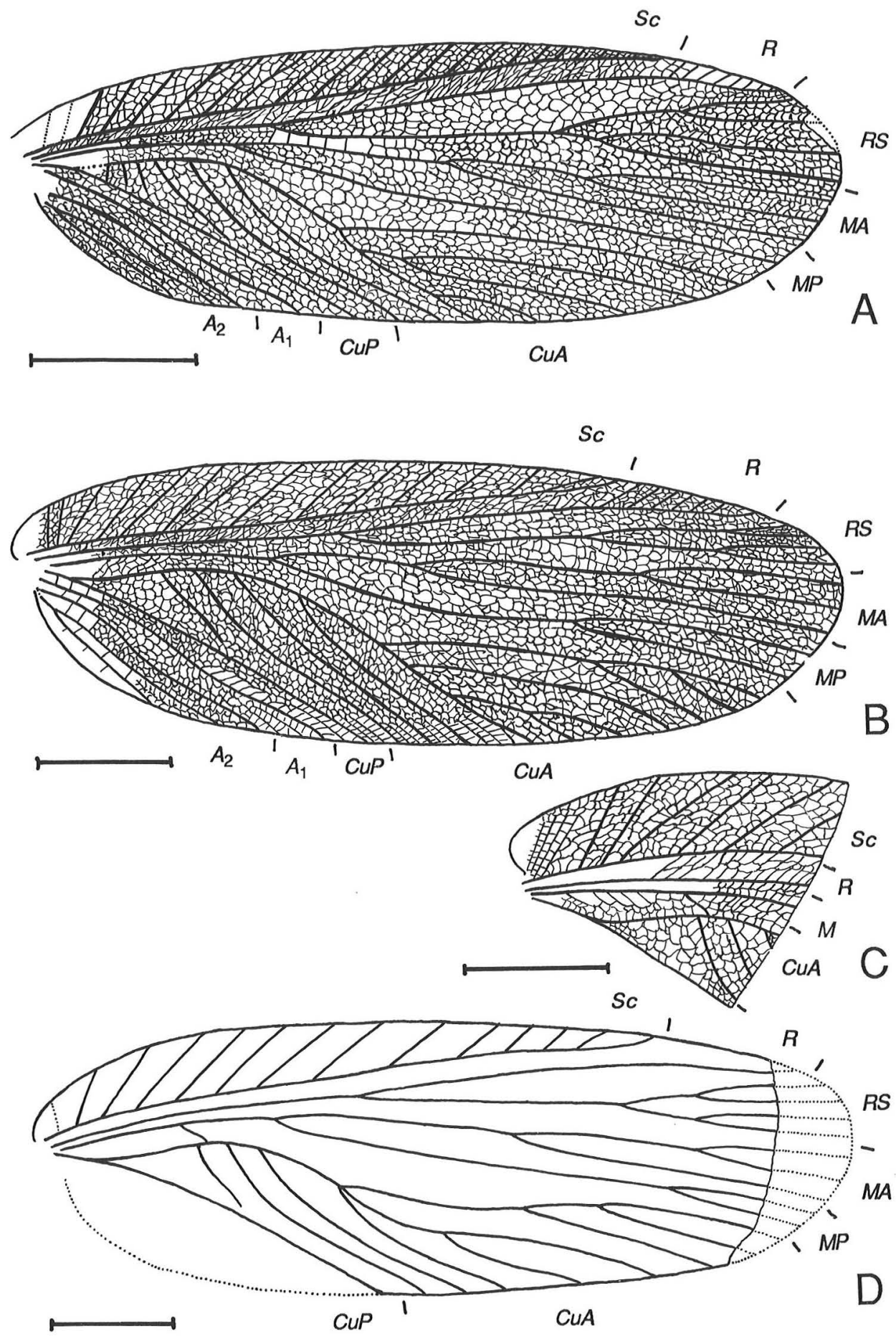

Fig. 9. Fore wings of Sojanidelia. - A: S. makarkini sp. n., holotype, spec. No 3353/167. - B-D: S. fluctuosa sp. n.; B: holotype, spec. No 3353/148; C: paratype, spec. No 3353/288; D: paratype, spec. No 3353/294. — Scale bars $5 \mathrm{~mm}$. 
Sojanidelia lineata Storozhenko, sp. n. Fig. 10A, B

Holotype: Fore wing without apex, imprint and counter-imprint, specimen No 3353/184; USSR: Arkhangelsk region, right bank of Sojana River about $57 \mathrm{~km}$ from its mouth, Iva-Gora; Upper Permian: Kazanian Stage; in collection of Paleontological Institute, Moscow.

Material: Holotype and 5 paratypes (all from Sojana River: Iva-Gora and Letopala): fore wing, specimen No $3353 / 130,816 / 117,861 / 117,872 / 117$ and $867 / 117 \& 876 /$ 117.

Locality and occurrence: USSR: Sojana River (IvaGora and Letopala); Upper Permian: Kazanian Stage.

Description: Fore wing 3.2-3.3 times longer than broad, with broadly rounded apex. Costal area with a series of 21-23 simple or branched veinlets; ratio of its maximum width to width of wing 5.1-5.3. $R S$ originating slightly beyond first third of wing, with 4-5 branches; $R S$ not united with $M A$, anastomosis between them absent. Maximum width of radial area 1.1-1.2 times less than width of costal area. $M$ with 3-4 branches; $M A$ with 2-3, MP simple. CuA with 8-9 branches; 3 proximal branches disappear in $\mathrm{CuA}$ $\mathrm{CuP}$ area; distal branch of $\mathrm{CuA}$ mostly simple, but in one case (specimen No 3353/130) bifurcate. $A_{1}$ simple, straight. $A_{2}$ with 4 branches. Archedictyon present in all areas. Fore wing light with longitudinal dark stripes across veins and costal area. Length of fore wing 36.5-38.4 mm, width 10.4-11.7 mm. Maximum width of costal area $2.0-2.1 \mathrm{~mm}$.

\section{Sojanidelia striata Storozhenko, sp. n.}

Fig. 10C, D

Holotype: Fore wing, imprint and counter-imprint, specimen No 845/117 \& 856/117; USSR: Arkhangelsk region, right bank of Sojana River about $60 \mathrm{~km}$ from its mouth, Letopala; Upper Permian: Kazanian Stage; in collection of Paleontological Institute, Moscow.

Material: Holotype and 3 paratypes (all from Sojana River: Iva-Gora and Letopala): fore wing, specimens No 94/559 \& 94/814, 94/780 \& 94/1132 and 796/117 \& 800/ 117.

Locality and occurrence: USSR: Sojana River (IvaGora and Letopala); Upper Permian: Kazanian Stage.

Description: Fore wing 3.2-3.5 times longer than broad, with broadly rounded apex. Costal area with a series of $15-17$ branched or simple veinlets; ratio of its width to width of wing 5.25.5. $R S$ originating at about first third of wing, with 4-5 branches; $R S$ united with $M A$ or with distinct anastomosis between them. Maximum width of radial area 1.1-1.3 times less than width of costal area. $M$ with 4-5 branches: $M A$ with 34, MP simple. CuA with $10-13$ branches; 4-5 proximal ones disappear in $C u A-C u P$ area; distal branch of $C u A$ with fork. $A_{1}$ simple, S-shaped. $A_{2}$ with 3 branches. Archedictyon present in all areas. Fore wing light, with longitudinal dark stripes across veins and costal area. Length of fore wing 37-39 mm, width 11-12 mm. Maximum width of costal area $2.0-2.3 \mathrm{~mm}$.

\section{Revision of the genus Permotermopsis}

\section{Permotermopsis Martynov, 1937}

Permotermopsis Martynov, 1937:84

Permotermopsis Sharov, 1962:121.

Type-species: Permotermopsis roseni Martynov, 1937, Upper Permian of Arkhangelsk region; by original designation.

Description: Fore wing membranous, without hairs. $S c$ terminating on $C$ near apical quarter of wing; costal area broad or narrow, 1.05-1.7 times broader than maximum width of radial area; with about 18-24 simple veinlets. $R$ simple; $R S$ with 67 branches, dichotomous or pectinate. $M$ forks proximally to origin of $R S ; M P$ branched. $C u A$ with about 7-9 branches terminating at posterior margin and a series of short straight branches terminating on $\mathrm{CuP}$; with regular simple crossveins between them. $\mathrm{CuP}$ simple, slightly curved. Cross-veins straight near base, forming rows of two cells in most areas and three cells in radial area. Anal area short and narrow.

Permotermopsis was described by Martynov (1937) from two incomplete imprints of fore wings, both without basal parts and posterior margins, from the Upper Permian of the Sojana River (Sheimo-Gora) and placed in a new family Permotermopsidae. Sharov (1962) transferred the genus to the family Ideliidae, but he did not formally mention Permotermopsidae as a synonym of the former. The full imprints of both species described by Martynov can be found in the collection of the Paleontological Institute, so 

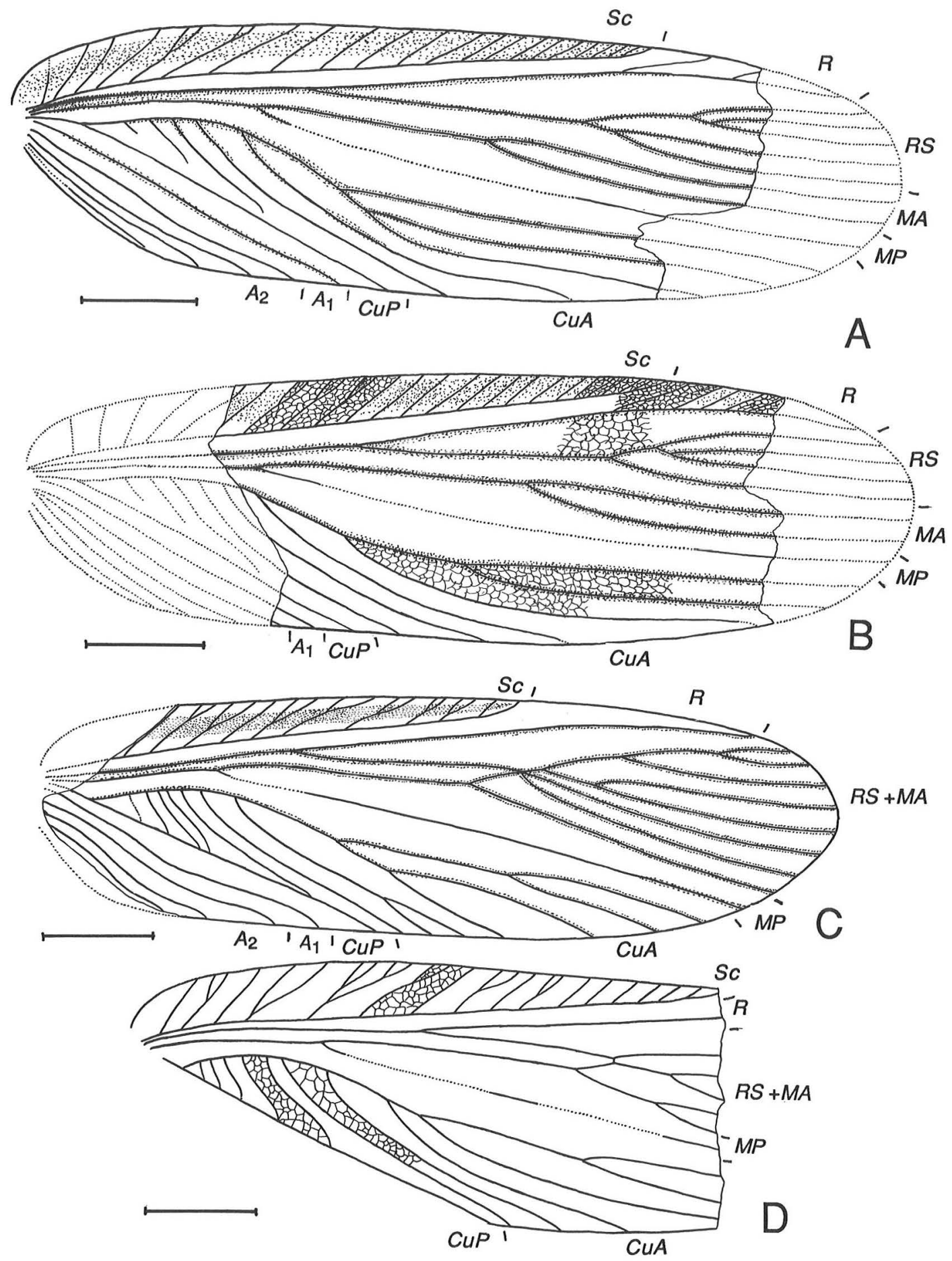

Fig. 10. Fore wings of Sojanidelia. - A, B: S. lineata sp. n.; A: holotype, spec. No 3353/184; B: paratype, spec. No 3353/130. - C, D: S. striata sp. n.; C: holotype, spec. No 845/177 \& 856/117; D: paratype, spec. No 94/780 \& 94/1132. - Scale bars $5 \mathrm{~mm}$. 
that the descriptions of the genus and species can be completed. The wing-venation shows that Permotermopsis is a member of the family Ideliidae; therefore Permotermopsidae is a younger synonym of the former.

Permotermopsis is closely related to Idelina gen. n., from which it is easily distinguished by the more branched $R S$ and by the presence of thick branches of $C u A$ in the $C u A-C u P$ area.

Species included: Two species from the Upper Permian of the Sojana River.

\section{Permotermopsis roseni Martynov, 1937}

Fig. 11A, B

Permotermopsis roseni Martynov, 1937:85, fig. 1. Permotermopsis roseni Sharov, 1962:121, fig. 291.

Holotype: Imprint of fore wing, specimen No 2334/ 335; USSR: Arkhangelsk region, right bank of Sojana River, Sheimo-Gora; Upper Permian: Kazanian Stage; in collection of Paleontological Institute, Moscow.

Material: Apart from holotype in collection of Paleontological Institute there are 4 additional fore wings from Sojana River (Iva-Gora and Letopala): specimens No 265/117 \& 266/117, 3353/172, 3353/285 and 3353/329.

Locality and occurrence: USSR: Sojana River (IvaGora, Sheimo-Gora and Letopala); Upper Permian: Kazanian Stage.

Description: Fore wing about 3 times longer than broad, with acutely rounded apex. Costal area with a series of 18-19 simple veinlets; ratio of its width to maximum width of radial area 1.6-1.7. Sc terminating at about $3 / 4$ of wing length; subcostal area narrow. $R S$ with 6-7 branches, dichotomous. $M$ dividing well before origin of $R S ; M A$ simple or with 2 branches; $M P$ with 3 branches, first fork of $M P$ far from origin of $R S$. Length of fore wing $54-55 \mathrm{~mm}$.

\section{Permotermopsis pectinata Martynov, 1937} Fig. 11C

\section{Permotermopsis pectinata Martynov, 1937:86, fig. 2.}

Holotype: Imprint of fore wing, specimen No 2334/ 363; USSR: Arkhangelsk region, right bank of Sojana River, Sheimo-Gora; Upper Permian: Kazanian Stage; in collection of Paleontological Institute, Moscow, probably lost.
Material: In the collection of the Paleontological Institute there are 5 additional fore wings known from Sojana River (Iva-Gora and Letopala): specimens No 815/117 \& $831 / 117,830 / 117 \& 837 / 117,94 / 115$ \& 94/116, 3353/283 and 3353/375. Holotype not found.

Locality and horizon: USSR: Sojana River (Iva-Gora, Sheimo-Gora and Letopala); Upper Permian: Kazanian Stage.

Description: Fore wing about 3 times longer than broad, with pointed apex. Costal area with a series of 20-24 simple veinlets; ratio of its width to width of radial area only $1.05-1.1$. Sc terminating at about $3 / 4$ of the wing length; subcostal area narrow. $R S$ with $6-7$ branches, pectinate. $M$ dividing well before origin of RS; $M A$ with 2 branches; $M P$ with 3, first fork of $M P$ near origin of $R S . A_{1}$ with $3-4, A_{2}$ with 5-6 branches. Length of fore wing $52-61 \mathrm{~mm}$.

$P$. pectinata differs from $P$. roseni by the more proximal first fork of MP, the narrow costal area and the pectinate $R S$.

Acknowledgements. I thank Dr. A. P. Rasnitsyn (Paleontological Institute, Moscow) for loaning me the material for this study.

\section{References}

Martynov, A. V. (Мартынов, А. В.) 1937: Wings of termites and phylogeny of Isoptera and allied groups of insects. (In Russian with English summary) - In: A l'academian N. V. Nassonov: 83-180. Moscow.

Hennig, W. 1981: Insect phylogeny. — John Wiley \& Sons, New York. 514 pp.

Kukalova, J. 1964: Permian insects of Moravia. Part II. Liomopteridea. - Sbornik Geolog. Ved., Paleontol. 3:39-118.

Rasnitsyn, A. Р. (Расницын, А. П.) 1976: [Grylloblattids are the recent representatives of the order Protoblattodea (Insecta, Protoblattodea).] (In Russian) Dokl. Acad. Sci. USSR 228(2):502 - 504.

- 1980: [Order Grylloblattida Walker, 1914.] (In Russian). - In: Rodendorf, B. B. \& Rasnitsyn, A. P. (Родендорф, Б. Б. \& Расницын, А. П.) (eds.), [The historical development of the class insecta.] Trudy Paleontol. Inst. Acad. Sci. USSR 175:150-154.

Sharov, A. G. (Шаров, А. Г.) 1961 : [Order Paraplecoptera.] (In Russian) — In: Rodendorf, B. B, BekkerMigdisova, E. E, Martynova, O. M. \& Sharov, A. G. (Родендорф, Б. Б, Беккер-Мигдисова, Е. Э, Мартынова, О. М. \& Щаров, А. Г.) [Palaeozoic insects from the Kuznetsk basin.] Trudy Paleontol. Inst. Acad. Sci. USSR 85:164-224. 

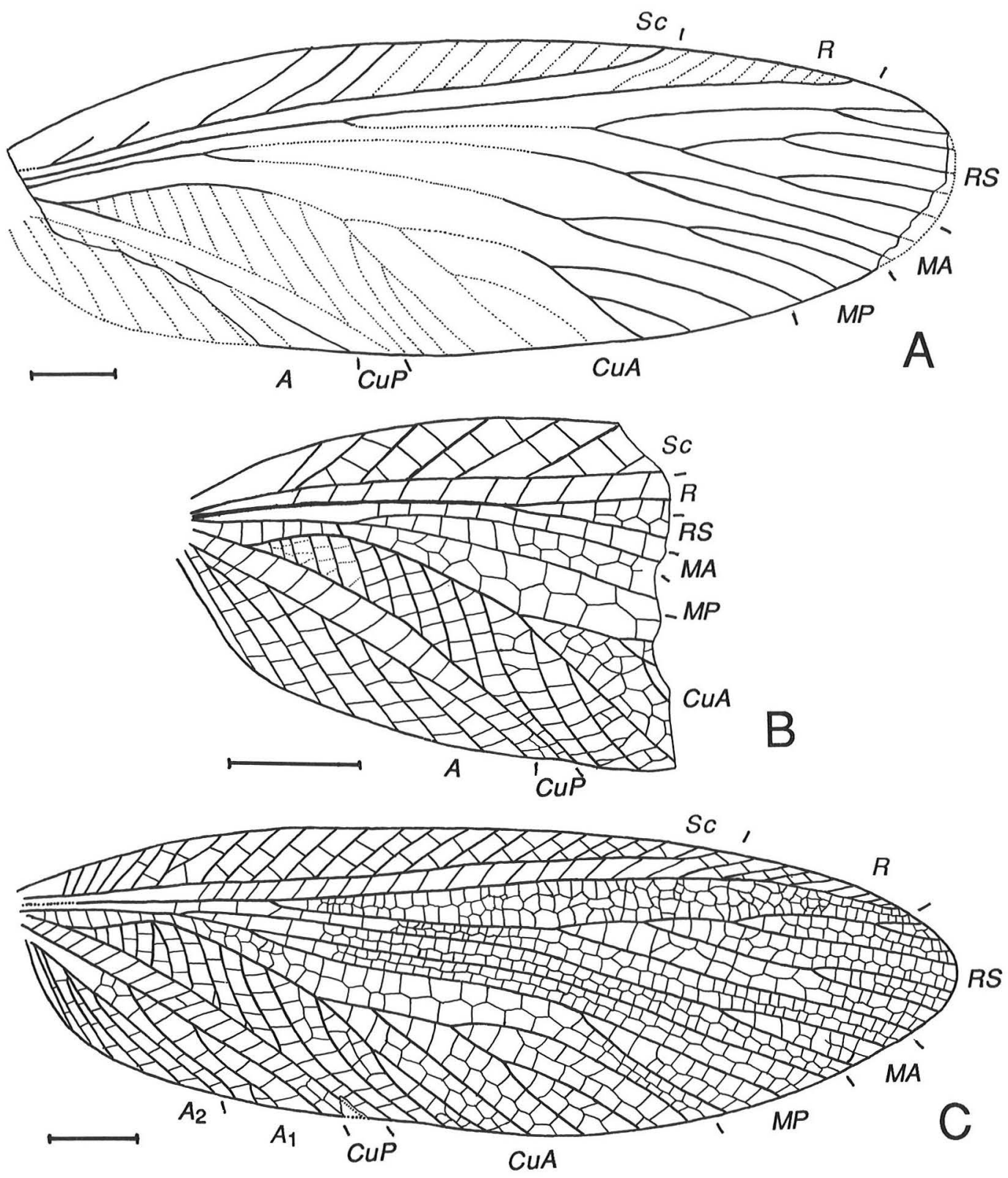

Fig. 11. Fore wings of Permotermopsis. - A, B: P. roseni Martynov; A: spec. No 3353/286; B: spec. No 3353/ 172. - C: P. pectinata Martynov, spec. No 3353/375. — Scale bars $5 \mathrm{~mm}$.

- 1962: [Order Paraplecoptera.] (In Russian) - In: Rodendorf, В. В. (Родендорф, Б. Б.) (ed.) [Fundamentals of paleontology. Arthropoda - Tracheata and Chelicerata.] Izd. Nauka, Moscow 9:119-134.

Storozhenko, S. Yu. (Стороженко, C. Ю.) 1988: [New and little-known Mesozoic Grylloblattida (Insecta).] (In Russian) - Paleontol. Zh. 4:48-54.
- 1990: Permian fossil insects of North-East Europe: revision of the family Atactophlebiidae (Ins. Gerarida, Atactophlebiidae). — Deutsche Entomol. Zeit. 37(45):407-412.

Received 19.I.1990, revised 11.III.1991 